\title{
Marker-assisted selection provides arabica coffee with genes from other Coffea species targeting on multiple resistance to rust and coffee berry disease
}

\author{
Emilly Ruas Alkimim • Eveline Teixeira Caixeta • Tiago Vieira Sousa • \\ Antônio Alves Pereira • Antonio Carlos Baião de Oliveira • Laércio Zambolim • \\ Ney Sussumu Sakiyama
}

Received: 27 September 2016 / Accepted: 14 December 2016

C) Springer Science+Business Media Dordrecht 2017

\begin{abstract}
Selecting superior genotypes is facilitated by marker-assisted selection (MAS), which is particularly suitable for transferring disease resistance alleles because it nullifies environmental effects and allows selection of resistant individuals in the absence of the pathogen or race, enabling preventive breeding. Molecular markers linked to two major genes $\left(\mathrm{S}_{\mathrm{H}} 3\right.$ and $\mathrm{S}_{\mathrm{H}}$ ?),
\end{abstract}

Electronic supplementary material The online version of this article (doi:10.1007/s11032-016-0609-1) contains supplementary material, which is available to authorized users.

E. R. Alkimim - T. V. Sousa

BIOAGRO, BioCafé, Universidade Federal de Viçosa, Viçosa, MG 36570-000, Brazil

\section{E. T. Caixeta $(\square)$}

Empresa Brasileira de Pesquisa Agropecuária - Embrapa Café, BIOAGRO, BioCafé, Universidade Federal de Viçosa, Viçosa, MG 36570-000, Brazil

e-mail: eveline.caixeta@embrapa.br

\section{A. A. Pereira}

Empresa de Pesquisa Agropecuária de Minas Gerais -Epamig, Viçosa, MG 36570-000, Brazil

A. C. B. de Oliveira

Embrapa Café, Viçosa, MG 36570-000, Brazil

L. Zambolim

Departamento de Fitopatologia, Universidade Federal de Viçosa, Viçosa, MG 36570-000, Brazil

N. S. Sakiyama

Departamento Fitotecnia, Universidade Federal de Viçosa, Viçosa, MG 36570-000, Brazil conferring resistance to coffee rust, and those linked to the $C k-1$ gene, conferring resistance to coffee berry disease (CBD), have previously been identified. These markers were validated and used in a progeny of crosses between Indian selections with Coffea arabica cultivars. Eleven resistant individuals homozygous for $\mathrm{S}_{\mathrm{H}} 3$ were identified by MAS. Of these, seven carry $\mathrm{S}_{\mathrm{H}}$ ? from Híbrido de Timor and the gene introduced from Coffea liberica $\left(\mathrm{S}_{\mathrm{H}} 3\right) . \mathrm{S}_{\mathrm{H}}$ ? was characterized as derived from Coffea canephora. Thus, it was possible to identify C. arabica genotypes carrying important genes for rust resistance introgressed from other coffee species. MAS also allowed identification of sources of CBD resistance for use in preventive breeding for resistance to this serious disease. Using two validated molecular markers, two coffee plants carrying $C k-1$ were identified: the UFV 328-60 genotype $\left(\mathrm{F}_{2}\right)$ was resistant and homozygous based on both molecular markers but exhibited no markers related to $\mathrm{S}_{\mathrm{H}} 3$ and $\mathrm{S}_{\mathrm{H}}$ ?, and the UFV 31712 genotype $\left(\mathrm{F}_{1}\right)$ was resistant and homozygous but resistant and heterozygous based on CBD-Sat207 and CBD-Sat235, respectively. Along with possessing $C k$ 1, the latter carries $\mathrm{S}_{\mathrm{H}}$ ? . Overall, plants carrying different genes for resistance to rust and CBD were identified. These plants are important sources for gene pyramiding in breeding programs aimed at multiple and durable resistance.

\section{Keywords Colletotrichum kahawae Hemileia} vastatrix . Preventive breeding - Gene pyramiding . Indian selections 


\section{Introduction}

Coffee is one of the most popular beverages worldwide. Coffee berries are the most traded tropical agricultural commodity and are crucial to the economy of many countries (Cenci et al. 2012), yet coffee production is limited by a number of diseases, including coffee rust caused by the fungus Hemileia vastatrix Berk. and $\mathrm{Br}$. (Agwanda et al. 1997). This fungus is the major constraint for cultivation of Coffea arabica, the most marketed coffee species worldwide.

Resistance to coffee rust is conferred by at least nine dominant genes $\left(\mathrm{S}_{\mathrm{H}} 1\right.$ to $\left.\mathrm{S}_{\mathrm{H}} 9\right)$, either singly or in combination. However, the resistance genes identified in C. arabica $\left(\mathrm{S}_{\mathrm{H}} 1, \mathrm{~S}_{\mathrm{H}} 2, \mathrm{~S}_{\mathrm{H}} 4\right.$, and $\left.\mathrm{S}_{\mathrm{H}} 5\right)$ have been overcome by existing rust races around the world, which is likely due to the high genetic variability of the fungus (Cabral et al. 2009; Fernandez et al. 2012; Maia et al. 2013).

Genes $\mathrm{S}_{\mathrm{H}} 5$ to $\mathrm{S}_{\mathrm{H}} 9$ have been identified in Híbrido de Timor, a coffee plant resulting from the natural cross between C. arabica $\times$ Coffea canephora (Bettencourt and Rodrigues 1988). Gene $\mathrm{S}_{\mathrm{H}} 5$ comes from C. arabica and genes $\mathrm{S}_{\mathrm{H}} 6$ to $\mathrm{S}_{\mathrm{H}} 9$ from $C$. canephora. In contrast, the $\mathrm{S}_{\mathrm{H}} 3$ gene was identified in Indian selections, which are derived from natural crosses between C. arabica $\times$ Coffea liberica, backcrossed or not with the Arabic cultivars Kent or Coorg (Bettencourt and Rodrigues 1988; Prakash et al. 2004; Ram 2006; Prakash et al. 2011).

Híbrido de Timor and Indian selections, which are tetraploid materials, are used to facilitate introgression of genes of interest from species with ploidy levels (C. canephora and C. liberica) that differ from that of $C$. arabica. Indeed, genes from $C$. canephora $\left(\mathrm{S}_{\mathrm{H}} 6\right.$ and $\left.\mathrm{S}_{\mathrm{H}} 9\right)$ and $C$. liberica $\left(\mathrm{S}_{\mathrm{H}} 3\right)$ have provided durable resistance in coffee plants evaluated in the field (Bettencourt and Rodrigues 1988; de Brito et al. 2010; Diola et al. 2011).

In an attempt to assist introgression of genes from other species into C. arabica, Prakash et al. (2004) identified 21 amplified fragment length polymorphism (AFLP) markers linked to the $\mathrm{S}_{\mathrm{H}} 3$ gene derived from introgression of C. liberica into C. arabica, and Mahé et al. 2008 converted four AFLP markers identified by Prakash et al. (2004) into sequence-characterized amplified region (SCAR) markers. These authors developed another three SCAR markers using a bacterial artificial chromosome (BAC) genomic library and three simple sequence repeat (SSR) markers co-segregating with the $\mathrm{S}_{\mathrm{H}} 3$ resistance gene.

de Brito et al. (2010) characterized one of the resistance genes found in Híbrido de Timor using accession UFV 427-15, which presents dominant monogenic resistance, and named the gene $\mathrm{S}_{\mathrm{H}}$ ? According to the authors, this gene corresponds to one of the $\mathrm{S}_{\mathrm{H}}$ genes $\left(\mathrm{S}_{\mathrm{H}} 7, \mathrm{~S}_{\mathrm{H}} 8\right.$, or $\left.\mathrm{S}_{\mathrm{H}} 9\right)$ previously identified in genotypes derived from Híbrido de Timor or another unknown gene. Later, de Brito et al. (2010) and Diola et al. (2011) identified molecular markers linked to the $\mathrm{S}_{\mathrm{H}}$ ? gene; Diola et al. (2011) also developed a high-density genetic map with six SCAR markers, delimiting a chromosomal region of $9.45 \mathrm{cM}$ and flanking the $\mathrm{S}_{\mathrm{H}}$ ? gene within 0.7 and $0.9 \mathrm{cM}$.

Another disease of great importance in coffee, coffee berry disease (CBD), is thus far restricted to the African continent, where it is considered one of the most devastating diseases, particularly at high elevations (Figueiredo et al. 2013). Nonetheless, this disease represents a great threat to coffee plantations in America and Asia, locations where the pathogen has not yet been detected. Such a threat justifies preventive studies and breeding in the search for resistant cultivars, efforts that can be achieved using molecular markers.

Based on heritage studies, Van Der Vossen and Walyaro 1980 proposed the existence of a locus (denominated T) in Híbrido de Timor conferring resistance to CBD. According to Agwanda et al. (1997) and Silva et al. (2006), resistance to CBD is controlled by at least three loci (T, R, and $\mathrm{K}$ ) present in Híbrido de Timor and Catimor (gene T), Rume Sudan (genes R and K), and K7 (gene K). In a study carried out by Gichuru et al. (2008), the locus identified as being responsible for resistance to Colletotrichum kahawae was termed $C k$ 1. Although these authors suggest that this locus is similar to the $\mathrm{T}$ locus described by Van Der Vossen and Walyaro (1980), they do not discard the possibility of the existence of another locus conferring resistance.

Using the cultivars Catimor 88 and Catimor 127 as a source of resistance, Gichuru et al. (2008) identified eight AFLP and two SSR markers linked to the gene for resistance to CBD. The gene termed $C k-1$ was found to be located in a segment of $11 \mathrm{cM}$.

Within this context, the availability of markers linked to genes of interest allows for identifying sources of resistance, even when the pathogen is absent. According to Ortega and Lopez-Vizcon (2012), when 
used at the appropriate stage of the breeding process, molecular markers closely related to resistance genes enable early selection of resistant individuals.

Moreover, compared to artificial inoculations, molecular markers are more rapid, inexpensive, and reliable for screening individuals with resistance genes. Thus, marker-assisted selection (MAS) is a powerful tool for increasing the efficiency of breeding programs, reducing the time required for selection, and allowing the search for durable, broad-spectrum resistance via the pyramiding of genes of interest (Gartner et al. 2013; Romero et al. 2014).

The goal of this study was to identify coffee plants carrying the genes $\mathrm{S}_{\mathrm{H}} 3$ and $\mathrm{S}_{\mathrm{H}}$ ?, which confer resistance to coffee rust. This study also constituted the beginning of a preventive breeding program in the search for resistance to $\mathrm{CBD}$, i.e., the $C k-1$ gene, for gene pyramiding and achieving multiple resistance. The MAS technique was used in a population derived from a cross between Indian selections and $C$. arabica cultivars of agronomic importance.

\section{Material and methods}

\section{Genetic material}

One hundred and sixty coffee plants obtained from crosses between dwarf (Caturra and Catuaí) and tall (Mundo Novo and others) cultivars of agronomic interest with coffee plants from India selected for carrying the $\mathrm{S}_{\mathrm{H}} 3$ gene were analyzed. The progeny used as sources of the $\mathrm{S}_{\mathrm{H}} 3$ gene included Indian selections S.288, S.333, S.353, S.795, and BA16. Indian selections S.288, S.333, and S.353 and the BA series are derived from the tetraploid coffee plants S.26 and S.31 (C. arabica $\times$ C. liberica) backcrossed or not with Kent or Coorg and carry the genes $\mathrm{S}_{\mathrm{H}} 2, \mathrm{~S}_{\mathrm{H}} 3$, and $\mathrm{S}_{\mathrm{H}} 5$. Online Resource 1 shows the genealogy of the study population.

The genetic material was introduced by the Plant Pathology Department of the Universidade Federal de Viçosa (UFV) to provide sources of resistance to rust for coffee breeding programs. The material was obtained from the Research Center for Coffee Rust, CIFC, in Oeiras, Portugal. After it was sent to Brazil, the genetic material was evaluated using a mixture of pathogen races collected in the states of Minas Gerais and Espírito Santo. Resistant coffee plants were planted at the adaptation and selection field in the experimental area of Fundão, UFV.

Validation of markers linked to the $\mathrm{S}_{\mathrm{H}} 3$ gene conferring resistance to coffee rust

Three genotypes carrying the $\mathrm{S}_{\mathrm{H}} 3$ gene (CIFC H147, CIFC H153/2, and S.288) and two susceptible genotypes (Caturra Vermelho (CIFC 19/1), and Catuaí Vermelho IAC 64 (UFV 2148/57)) were used for the validation of molecular markers. CIFC H147 and CIFC H153/2 correspond to hybrids resulting from crosses between the Indian selection S.353 with S4 Agaro and the Indian selection S.288 with Geisha, respectively. These coffee plants are differential clones of $H$. vastatrix races and possess the $\mathrm{S}_{\mathrm{H}} 3$ gene, which allows for identification of pathogen races carrying the virulence gene v3.

Young, fully expanded leaves of these five coffee plants were collected, and DNA was extracted using the methodology described by Diniz et al. (2005). The DNA from these plants was amplified using four SCAR markers (SP-M8-S ${ }_{\mathrm{H}} 3$, SP-M16-S $\mathrm{H}_{\mathrm{H}} 3$, BA-48-21O-f, and BA-124-12K-f) and an SSR marker (Sat244), which correspond to five of the ten markers identified by Mahé et al. (2008) as being linked to the $\mathrm{S}_{\mathrm{H}} 3$ gene. Markers mapped in coupling and near the gene were selected for this study.

PCR amplification was carried out in a final volume of $25 \mu \mathrm{L}$ containing $50 \mathrm{ng}$ genomic DNA, $1 \times$ Taq DNA polymerase buffer, $2.0 \mathrm{mM} \mathrm{MgCl} 2,0.1 \mathrm{mM}$ dNTPs, $0.4 \mu \mathrm{M}$ each primer, and 0.5 units Taq DNA polymerase. Reactions were carried out using PTC-200 (MJ Research) and Veriti (Applied Biosystems) thermocyclers, with the following conditions: initial denaturation for $5 \mathrm{~min}$ at $95{ }^{\circ} \mathrm{C}, 35$ cycles of $45 \mathrm{~s}$ at $94{ }^{\circ} \mathrm{C}$, annealing for $45 \mathrm{~s}$ at temperatures specific for each primer, extension for $45 \mathrm{~s}$ at $72{ }^{\circ} \mathrm{C}$, and a final extension for $10 \mathrm{~min}$ at $72{ }^{\circ} \mathrm{C}$.

Validation of SCAR markers linked to the $\mathrm{S}_{\mathrm{H}}$ ? gene from Híbrido de Timor conferring resistance to coffee rust

At this validation step, DNA was used from accessions Híbrido de Timor UFV 427-15 and UFV 443-03 and the genotype UFV H421-4, carrying the resistance gene $\mathrm{S}_{\mathrm{H}}$ ? The genotypes Catuaí Amarelo IAC 30 (UFV 2143-236) and Catuaí Vermelho IAC 64 (UFV 2148-57) were used as susceptible controls. In the study carried out by Diola 
et al. (2011), the authors used UFV 427-15 and UFV 2143-236 as parents and UFV H421-4 as the $\mathrm{F}_{1}$ plant to identify molecular markers linked to the $\mathrm{S}_{\mathrm{H}}$ ? gene.

Amplification was carried out using six SCAR markers (CaRHvII 1, CaRHvII 2, CaRHvII 3, CaRHvII 4, CaRHvII 5, and CaRHvII 6) previously identified by Diola et al. (2011). Reactions were carried out using PTC-200 (MJ Research) and Veriti (Applied Biosystems) thermocyclers with 100 ng genomic DNA, $1 \times$ Taq DNA polymerase buffer, $1.5 \mathrm{mM} \mathrm{MgCl}_{2}$, $0.2 \mathrm{mM}$ dNTPs, $0.25 \mu \mathrm{M}$ each primer, 0.5 unit Taq DNA polymerase, and ultrapure water to complete the final volume of $20 \mu \mathrm{L}$. Amplification consisted of an initial denaturation step at $95^{\circ} \mathrm{C}$ for $5 \mathrm{~min}, 35$ cycles at $94{ }^{\circ} \mathrm{C}$ for $30 \mathrm{~s}$, annealing at temperatures specific for each primer for $30 \mathrm{~s}$, extension at $72{ }^{\circ} \mathrm{C}$ for $60 \mathrm{~s}$, and a final extension at $72{ }^{\circ} \mathrm{C}$ for $10 \mathrm{~min}$.

Validation of SSR markers linked to the $C k-1$ gene conferring resistance to coffee berry

Gichuru et al. (2008) identified and mapped two SSR markers linked to the gene for resistance to CBD. To validate these molecular markers linked to the $C k-1$ gene, accessions of Híbrido de Timor UFV 377-15 and UFV 440-10 and the cultivar MGS Catiguá 3 carrying the resistance gene were used as controls. Two control genotypes not carrying the resistance gene, Caturra Vermelho (CIFC 19/1) and Catuaí Vermelho IAC 64 (UFV 2148-57), were also included. Cultivar MGS Catiguá 3 is derived from the artificial cross between Catuaí Amarelo IAC 86 and Híbrido de Timor UFV 440-10.

PCR amplification was carried out in a total volume of $25 \mu \mathrm{L}$ containing $50 \mathrm{ng}$ genomic DNA, $1 \times$ Taq DNA polymerase buffer, $2.0 \mathrm{~mm} \mathrm{MgCl}_{2}, 0.1 \mathrm{mM}$ dNTPs, $0.4 \mu \mathrm{M}$ each primer, and 0.5 unit Taq DNA polymerase. Reactions were carried out using PTC-200 (MJ Research) and Veriti (Applied Biosystems) thermocyclers. The PCR program consisted of an initial denaturation step at $95^{\circ} \mathrm{C}$ for $5 \mathrm{~min}$, followed by 35 cycles at $95{ }^{\circ} \mathrm{C}$ for $45 \mathrm{~s}$, annealing for $45 \mathrm{~s}$ at temperatures specific for each primer, extension at $72{ }^{\circ} \mathrm{C}$ for $45 \mathrm{~s}$, and a final extension at $95^{\circ} \mathrm{C}$ for $10 \mathrm{~min}$.

Selection using molecular markers

For molecular analysis of the 160 coffee plants introduced by the Plant Pathology Department of UFV, DNA was extracted according to the methodology proposed by Diniz et al. (2005).

The DNA from these coffee plants was amplified with markers validated in the study. Polymorphisms were detected on $6 \%$ denaturing polyacrylamide gels stained with silver nitrate, according to the protocol described by de Brito et al. (2010).

The banding pattern of the 160 coffee plants was analyzed by comparing with that of the genotypes used as susceptible and resistant controls, as previously described. Gels were analyzed based on the presence or absence of the resistance marker. Moreover, it was possible to analyze whether the genotypes were homozygous or heterozygous for the gene evaluated based on molecular markers that showed codominant markers.

\section{Results}

Assisted selection for the $\mathrm{S}_{\mathrm{H}} 3$ gene conferring resistance to coffee rust

After adjusting the amplification conditions to validate the five molecular markers identified by Mahé et al. (2008), four showed strong bands and the expected band pattern. Online Resource 2 describes the validated molecular markers.

The four validated molecular markers were used for molecular analysis of the 160 coffee plants of the study population, the results of which are shown in Table 1. Considering the four molecular markers, 107 (66.87\%) individuals with the $\mathrm{S}_{\mathrm{H}} 3$ gene were identified (Table 2). When compared with the other molecular markers, BA48-21OR showed different results only for genotype UFV 316-13, which was found to be susceptible based on this molecular marker but resistant based on other markers (Fig. 1).
Table 1 Number of plants carrying $(+)$ and not carrying $(-)$ the marker linked to the gene $\mathrm{S}_{\mathrm{H}} 3$

\begin{tabular}{lll}
\hline Marker & \multicolumn{2}{l}{ Plants } \\
\cline { 2 - 3 } & $(+)$ & $(-)$ \\
\hline SP-M16-S 33 & 108 & 52 \\
BA-124-12K-f & 108 & 52 \\
Sat244 & 108 & 52 \\
BA-48-21OR & 107 & 53 \\
\hline
\end{tabular}


Table 2 Resistant genotypes of coffee plants based on markers SP-M16-S 3 , Sat244, BA-4821OR, and BA-124-12K-f

\begin{tabular}{|c|c|c|c|}
\hline UFV $311-30\left(\mathrm{~F}_{2}\right)$ & UFV 317-69 $\left(\mathrm{F}_{1}\right)$ & UFV 335-08 $\left(\mathrm{F}_{2}\right)$ & UFV 399-23 $\left(\mathrm{F}_{1}\right)$ \\
\hline UFV $311-48\left(\mathrm{~F}_{2}\right)$ & UFV 327-04 $\left(\mathrm{F}_{2}\right)$ & UFV 335-12 $\left(\mathrm{F}_{2}\right)$ & UFV $339-25\left(\mathrm{~F}_{1}\right)$ \\
\hline UFV $311-49\left(\mathrm{~F}_{2}\right)$ & UFV $327-13\left(\mathrm{~F}_{2}\right)$ & UFV $335-13\left(\mathrm{~F}_{2}\right)$ & UFV 399-31 $\left(\mathrm{F}_{1}\right)$ \\
\hline UFV 311-56 $\left(\mathrm{F}_{2}\right)$ & UFV $327-16\left(\mathrm{~F}_{2}\right)$ & UFV $335-70\left(\mathrm{~F}_{2}\right)$ & UFV $399-45\left(\mathrm{~F}_{2}\right)$ \\
\hline UFV 311-63 $\left(\mathrm{F}_{2}\right)$ & UFV $327-89\left(F_{2}\right)$ & UFV 335-77 $\left(\mathrm{F}_{2}\right)$ & UFV $339-100\left(F_{1}\right)$ \\
\hline UFV 312-96 $\left(\mathrm{F}_{2}\right)$ & UFV $328-43\left(\mathrm{~F}_{2}\right)$ & UFV 335-104 $\left(\mathrm{F}_{2}\right)$ & UFV 402-01 $\left(\mathrm{F}_{2}\right)$ \\
\hline UFV 313-96 $\left(\mathrm{F}_{2}\right)$ & UFV $328-62\left(\mathrm{~F}_{2}\right)$ & UFV 335-121 $\left(\mathrm{F}_{2}\right)$ & UFV 402-02 $\left(\mathrm{F}_{2}\right)$ \\
\hline UFV 313-107 $\left(\mathrm{F}_{2}\right)$ & UFV 329-01 $\left(\mathrm{F}_{2}\right)$ & UFV 335-130 $\left(\mathrm{F}_{2}\right)$ & UFV 402-21 $\left(\mathrm{F}_{2}\right)$ \\
\hline UFV 313-133 $\left(\mathrm{F}_{2}\right)$ & UFV $329-63\left(\mathrm{~F}_{2}\right)$ & UFV 336-01 ( $\left.\mathrm{F}_{1}\right)$ & UFV 402-36 $\left(\mathrm{F}_{2}\right)$ \\
\hline UFV 314-44 $\left(\mathrm{F}_{2}\right)$ & UFV 329-72 $\left(\mathrm{F}_{2}\right)$ & UFV 336-02 $\left(\mathrm{F}_{1}\right)$ & UFV 402-38 $\left(\mathrm{F}_{2}\right)$ \\
\hline UFV $315-02\left(\mathrm{~F}_{2}\right)$ & UFV $329-78\left(\mathrm{~F}_{2}\right)$ & UFV 336-04 $\left(\mathrm{F}_{1}\right)$ & UFV $402-49\left(\mathrm{~F}_{2}\right)$ \\
\hline UFV $315-50\left(\mathrm{~F}_{2}\right)$ & UFV 329-102 $\left(\mathrm{F}_{2}\right)$ & UFV 336-05 $\left(\mathrm{F}_{1}\right)$ & UFV 409-03 $\left(\mathrm{F}_{2}\right)$ \\
\hline UFV $315-76\left(\mathrm{~F}_{2}\right)$ & UFV 334-03 $\left(\mathrm{F}_{2}\right)$ & UFV 336-08 $\left(\mathrm{F}_{1}\right)$ & UFV 409-04 $\left(\mathrm{F}_{2}\right)$ \\
\hline UFV 316-12 $\left(\mathrm{F}_{1}\right)$ & UFV 334-07 $\left(\mathrm{F}_{2}\right)$ & UFV 336-10 $\left(\mathrm{F}_{1}\right)$ & UFV 409-05 $\left(\mathrm{F}_{2}\right)$ \\
\hline UFV $316-15\left(\mathrm{~F}_{1}\right)$ & UFV 334-08 $\left(\mathrm{F}_{2}\right)$ & UFV 336-34 $\left(\mathrm{F}_{1}\right)$ & UFV 409-06 $\left(\mathrm{F}_{2}\right)$ \\
\hline UFV $316-21\left(\mathrm{~F}_{1}\right)$ & UFV 334-09 $\left(\mathrm{F}_{2}\right)$ & UFV 336-39 $\left(\mathrm{F}_{1}\right)$ & UFV 409-08 $\left(\mathrm{F}_{2}\right)$ \\
\hline UFV $316-32\left(\mathrm{~F}_{1}\right)$ & UFV 334-63 $\left(\mathrm{F}_{2}\right)$ & UFV 337-01 $\left(\mathrm{F}_{1}\right)$ & UFV 409-12 $\left(\mathrm{F}_{2}\right)$ \\
\hline UFV $316-33\left(\mathrm{~F}_{1}\right)$ & UFV 334-64 $\left(\mathrm{F}_{2}\right)$ & UFV 337-16 $\left(\mathrm{F}_{1}\right)$ & UFV 409-30 $\left(\mathrm{F}_{2}\right)$ \\
\hline UFV 316-35 $\left(\mathrm{F}_{1}\right)$ & UFV 334-65 $\left(\mathrm{F}_{2}\right)$ & UFV 337-18 $\left(\mathrm{F}_{1}\right)$ & UFV 409-34 $\left(\mathrm{F}_{2}\right)$ \\
\hline UFV $316-43\left(\mathrm{~F}_{1}\right)$ & UFV 334-66 $\left(\mathrm{F}_{2}\right)$ & UFV 337-19 $\left(\mathrm{F}_{1}\right)$ & UFV 409-36 $\left(\mathrm{F}_{2}\right)$ \\
\hline UFV $316-59\left(\mathrm{~F}_{1}\right)$ & UFV 334-67 $\left(\mathrm{F}_{2}\right)$ & UFV $337-20\left(F_{1}\right)$ & UFV $409-42\left(\mathrm{~F}_{2}\right)$ \\
\hline UFV 316-69 $\left(\mathrm{F}_{1}\right)$ & UFV 334-93 $\left(\mathrm{F}_{2}\right)$ & UFV 337-29 $\left(\mathrm{F}_{1}\right)$ & UFV 409-48 $\left(\mathrm{F}_{2}\right)$ \\
\hline UFV $316-70\left(\mathrm{~F}_{1}\right)$ & UFV 334-139 $\left(\mathrm{F}_{2}\right)$ & UFV $337-30\left(\mathrm{~F}_{1}\right)$ & UFV 480-06 $\left(\mathrm{F}_{2}\right)$ \\
\hline UFV 317-01 $\left(\mathrm{F}_{1}\right)$ & UFV 335-03 $\left(\mathrm{F}_{2}\right)$ & UFV 339-01 $\left(\mathrm{F}_{1}\right)$ & UFV 480-11 $\left(\mathrm{F}_{2}\right)$ \\
\hline UFV $317-02\left(\mathrm{~F}_{1}\right)$ & UFV 335-04 $\left(\mathrm{F}_{2}\right)$ & UFV 339-02 $\left(\mathrm{F}_{1}\right)$ & UFV 480-14 $\left(\mathrm{F}_{2}\right)$ \\
\hline UFV $317-19\left(\mathrm{~F}_{1}\right)$ & UFV 335-06 $\left(\mathrm{F}_{2}\right)$ & UFV 339-07 $\left(\mathrm{F}_{1}\right)$ & UFV $480-15\left(\mathrm{~F}_{2}\right)$ \\
\hline UFV $317-59\left(\mathrm{~F}_{1}\right)$ & UFV 335-07 $\left(\mathrm{F}_{2}\right)$ & UFV 339-10 $\left(\mathrm{F}_{1}\right)$ & - \\
\hline
\end{tabular}

Of the validated molecular markers, three (SP-M16$\mathrm{S}_{\mathrm{H}} 3$, Sat244, and BA-48-21OR) presented codominant banding patterns, and one marker (BA-124-12K) presented a dominant banding pattern (Online Resource 3). Thus, in addition to analysis of the presence or absence of a resistance gene, individuals homozygous and heterozygous for the $\mathrm{S}_{\mathrm{H}} 3$ gene were selected by analysis of the molecular markers showing codominance (BA-48-21OR, Sat244, and SP-M16-S 3 ).
Coffee UFV 316-13 $\left(\mathrm{F}_{1}\right)$ presented no result when analyzing BA-48-21OR, whereas it was heterozygous and resistant according to markers SP-M16- $\mathrm{S}_{\mathrm{H}} 3$ and Sat244. Coffee plants UFV 327-89 ( $\left.\mathrm{F}_{2}\right)$, UFV 334-07 $\left(\mathrm{F}_{2}\right)$, and UFV 335-70 $\left(\mathrm{F}_{2}\right)$ were resistant and heterozygous based on BA-48-21OR and resistant and homozygous based on another two codominant molecular markers. According to markers M16- $\mathrm{S}_{\mathrm{H}} 3$ and BA-4821OR, coffee UFV 334-63 $\left(\mathrm{F}_{2}\right)$ was resistant and

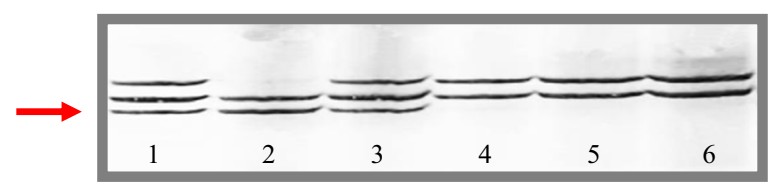

Fig. 1 Amplification of three control genotypes with the $\mathrm{S}_{\mathrm{H}} 3$ gene, CIFC H147 (1), S.288 (2), and CIFC H153/2 (3); two susceptible genotypes, Caturra Vermelho CIFC 19/1 (4) and Catuaí Vermelho IAC 64 (UFV 2148-57) (5); and studied coffee
UFV 316-13 (6) with the marker BA-48-21OR linked to the $\mathrm{S}_{\mathrm{H}} 3$ gene. The red arrow corresponds to the marker linked to the resistance allele 
homozygous, but it was resistant and heterozygous according to Sat244. BA-48-21OR and Sat244 indicated resistance and heterozygosity for coffee plant UFV 334$139\left(\mathrm{~F}_{2}\right)$, whereas M16- $\mathrm{S}_{\mathrm{H}} 3$ indicated resistance and homozygosity. Therefore, one recombinant with the molecular marker M16- $\mathrm{S}_{\mathrm{H}} 3$, four recombinants with BA-48-21OR, and one recombinant with Sat244 were obtained.

For greater efficiency regarding gene introgression in breeding programs, we selected a total of 11 resistant genotypes homozygous for the four molecular markers, as follows: UFV 311-48 $\left(\mathrm{F}_{2}\right)$, UFV 311-49 $\left(\mathrm{F}_{2}\right)$, UFV 311-56 $\left(\mathrm{F}_{2}\right)$, UFV 313-133 $\left(\mathrm{F}_{2}\right)$, UFV 329-72 $\left(\mathrm{F}_{2}\right)$, UFV 329-78 $\left(\mathrm{F}_{2}\right)$, UFV 334-65 $\left(\mathrm{F}_{2}\right)$, UFV 335-12 $\left(\mathrm{F}_{2}\right)$, UFV 335-77 $\left(\mathrm{F}_{2}\right)$, UFV 399-45 $\left(\mathrm{F}_{2}\right)$, and UFV 409-08 $\left(\mathrm{F}_{2}\right)$.

Assisted selection for the $\mathrm{S}_{\mathrm{H}}$ ? gene of Híbrido de Timor conferring resistance to coffee rust

Of the six SCAR molecular markers linked to the $\mathrm{S}_{\mathrm{H}}$ ? gene present in Híbrido de Timor, which were obtained in the study carried out by Diola et al. (2011), three were validated. Online Resource 4 provides a description of these markers.

Molecular analysis of the 160 coffee plants was carried out based on the banding patterns presented by the control genotypes, with or without the resistance gene. In this case, it was only possible to observe the presence or absence of a marker linked to the resistance gene because the three validated molecular markers presented dominant banding patterns (Online Resource 5).

Table 3 and Online Resource 6 show the results of analysis of the SCAR markers linked to the $\mathrm{S}_{\mathrm{H}}$ ? gene. Through analysis of the three molecular markers, 129 $(80.63 \%)$ of the individuals were considered to be resistant due to the presence of the gene. Of these 129 genotypes carrying the $\mathrm{S}_{\mathrm{H}}$ ? gene from Híbrido de Timor, 44 were among the 52 genotypes identified in the previous analysis as not carrying the $\mathrm{S}_{\mathrm{H}} 3$ gene, even though they were introduced to Brazil as potential

Table 3 Number of plants carrying (+) and not carrying $(-)$ the marker linked to the gene $\mathrm{S}_{\mathrm{H}}$ ?

\begin{tabular}{lll}
\hline SCAR marker & \multicolumn{2}{l}{ Plants } \\
\cline { 2 - 3 } & $(+)$ & $(-)$ \\
\hline CaRHvII 2 & 138 & 22 \\
CaRHvII 3 & 129 & 31 \\
CaRHvII 5 & 132 & 28 \\
\hline
\end{tabular}

sources of resistance to rust and as carrying the $\mathrm{S}_{\mathrm{H}} 3$ gene. The 44 coffee plants are listed in Table 4.

According to recombination analysis, coffee plants UFV 328-69 $\left(\mathrm{F}_{2}\right)$, UFV 334-03 $\left(\mathrm{F}_{2}\right)$, UFV 334-09 $\left(\mathrm{F}_{2}\right)$, UFV 334-63 $\left(\mathrm{F}_{2}\right)$, and UFV 335-13 $\left(\mathrm{F}_{2}\right)$ did not present the $\mathrm{S}_{\mathrm{H}}$ ? gene for molecular markers CaRHvII 3 and CaRHvII 5 but did present the marker to CaRHvII 2. For coffee plants UFV 329-63 $\left(\mathrm{F}_{2}\right)$, UFV 335-03 $\left(\mathrm{F}_{2}\right)$, UFV 402-49 $\left(\mathrm{F}_{2}\right)$, and UFV 409-04 $\left(\mathrm{F}_{2}\right)$, the marker for CaRHvII 2 and CaRHvII 5 was present, whereas for CaRHvII 3, the marker was absent. Coffee UFV 334-04 $\left(\mathrm{F}_{2}\right)$ presented a marker when analyzing with CaRHvII 2 and CaRHvII 3, though the marker for CaRHvII 5 was absent. Therefore, five recombinants were obtained using CaRHvII 2, four using CaRHvII 3 , and only one using CaRHvII 5.

Through analysis of molecular markers linked to both rust resistance genes $\left(\mathrm{S}_{\mathrm{H}} 3\right.$ and $\mathrm{S}_{\mathrm{H}}$ ?), coffee plants UFV 311-48 $\left(\mathrm{F}_{2}\right)$, UFV 311-49 $\left(\mathrm{F}_{2}\right)$, UFV 311-56 $\left(\mathrm{F}_{2}\right)$, UFV 313-133 $\left(\mathrm{F}_{2}\right)$, UFV 334-65 $\left(\mathrm{F}_{2}\right)$, UFV 399-45 $\left(\mathrm{F}_{2}\right)$, and UFV 409-08 $\left(\mathrm{F}_{2}\right)$ were identified as being homozygous for the $\mathrm{S}_{\mathrm{H}} 3$ gene and carrying the $\mathrm{S}_{\mathrm{H}}$ ? gene of Híbrido de Timor.

Assisted selection for the $C k-1$ gene conferring resistance to coffee berry disease

Aiming at preventive breeding and analysis of genotypes carrying resistance to rust, two SSR molecular markers, which were identified and mapped by Gichuru et al. (2008), were validated as being linked to the $C k-1$ gene, which confers coffee plants with resistance to coffee berry disease (Online Resource 7, Online Resource 8).

Three coffee plants carrying the $C k-1$ gene, UFV 317-12 $\left(\mathrm{F}_{1}\right)$, UFV 328-60 $\left(\mathrm{F}_{2}\right)$, and UFV 334-68 $\left(\mathrm{F}_{2}\right)$, were identified by analysis of the CBD-Sat235. However, only plants UFV 317-12 $\left(\mathrm{F}_{1}\right)$ and UFV 328$60\left(\mathrm{~F}_{2}\right)$ were identified as carrying the resistance gene when using CBD-Sat207.

Based on CBD-Sat235, coffee UFV 334-68 $\left(\mathrm{F}_{2}\right)$ was resistant and heterozygous, but it was susceptible according to CBD-Sat207. Although genotype UFV 328-60 $\left(\mathrm{F}_{2}\right)$ was resistant and homozygous with both molecular markers, it showed no markers linked to $\mathrm{S}_{\mathrm{H}} 3$ and $\mathrm{S}_{\mathrm{H}}$ ? Conversely, coffee UFV 317-12 $\left(\mathrm{F}_{1}\right)$ presented the gene for resistance to $\mathrm{CBD}$ and was homozygous for the locus in relation with CBD-Sat207 but resistant and heterozygous when analyzing CBD- 
Table 4 Coffee plants without the resistance marker for the $\mathrm{S}_{\mathrm{H}} 3$ gene but with the marker for the $\mathrm{S}_{\mathrm{H}}$ ? gene from Híbrido de Timor

\begin{tabular}{llll}
\hline UFV 311-27 $\left(\mathrm{F}_{2}\right)$ & UFV 317-60 $\left(\mathrm{F}_{1}\right)$ & UFV 336-35 $\left(\mathrm{F}_{1}\right)$ & UFV 409-16 $\left(\mathrm{F}_{2}\right)$ \\
UFV 315-01 $\left(\mathrm{F}_{2}\right)$ & UFV 327-11 $\left(\mathrm{F}_{2}\right)$ & UFV 336-37 $\left(\mathrm{F}_{1}\right)$ & UFV 409-18 $\left(\mathrm{F}_{2}\right)$ \\
UFV 315-04 $\left(\mathrm{F}_{2}\right)$ & UFV 327-18 $\left(\mathrm{F}_{2}\right)$ & UFV 339-34 $\left(\mathrm{F}_{1}\right)$ & UFV 409-20 $\left(\mathrm{F}_{2}\right)$ \\
UFV 315-06 $\left(\mathrm{F}_{2}\right)$ & UFV 327-117 $\left(\mathrm{F}_{2}\right)$ & UFV 339-65 $\left(\mathrm{F}_{1}\right)$ & UFV 409-29 $\left(\mathrm{F}_{2}\right)$ \\
UFV 315-15 $\left(\mathrm{F}_{2}\right)$ & UFV 335-01 $\left(\mathrm{F}_{2}\right)$ & UFV 341-15 $\left(\mathrm{F}_{2}\right)$ & UFV 409-41 $\left(\mathrm{F}_{2}\right)$ \\
UFV 315-143 $\left(\mathrm{F}_{2}\right)$ & UFV 335-05 $\left(\mathrm{F}_{2}\right)$ & UFV 399-33 $\left(\mathrm{F}_{2}\right)$ & UFV 409-43 $\left(\mathrm{F}_{2}\right)$ \\
UFV 316-17 $\left(\mathrm{F}_{1}\right)$ & UFV 335-15 $\left(\mathrm{F}_{2}\right)$ & UFV 402-04 $\left(\mathrm{F}_{2}\right)$ & UFV 409-47 $\left(\mathrm{F}_{2}\right)$ \\
UFV 316-66 $\left(\mathrm{F}_{1}\right)$ & UFV 335-16 $\left(\mathrm{F}_{2}\right)$ & UFV 404-01 $\left(\mathrm{F}_{2}\right)$ & UFV 409-49 $\left(\mathrm{F}_{2}\right)$ \\
UFV 317-12 $\left(\mathrm{F}_{1}\right)$ & UFV 335-124 $\left(\mathrm{F}_{2}\right)$ & UFV 409-01 $\left(\mathrm{F}_{2}\right)$ & UFV 409-51 $\left(\mathrm{F}_{2}\right)$ \\
UFV 317-22 $\left(\mathrm{F}_{1}\right)$ & UFV 336-06 $\left(\mathrm{F}_{1}\right)$ & UFV 409-13 $\left(\mathrm{F}_{2}\right)$ & UFV 480-12 $\left(\mathrm{F}_{2}\right)$ \\
UFV 317-52 $\left(\mathrm{F}_{1}\right)$ & UFV 336-29 $\left(\mathrm{F}_{1}\right)$ & UFV 409-14 $\left(\mathrm{F}_{2}\right)$ & UFV 480-26 $\left(\mathrm{F}_{2}\right)$ \\
\hline
\end{tabular}

Sat235. Furthermore, this coffee also carries the $\mathrm{S}_{\mathrm{H}}$ ? gene, which confers resistance to rust.

\section{Discussion}

Assisted selection for the $\mathrm{S}_{\mathrm{H}} 3$ gene conferring resistance to coffee rust

By analyzing the molecular markers SP-M16- $\mathrm{S}_{\mathrm{H}} 3$, Sat244, and BA-124-12K, which have been validated for the gene $\mathrm{S}_{\mathrm{H}} 3$, in a breeding population of 160 coffee plants, 108 were found to carry the resistance gene. For BA-48-21OR, 107 coffee plants contained the marker, which differed from the other markers only for coffee UFV 316-13 $\left(\mathrm{F}_{1}\right)$; this coffee plant presented no resistance marker and most likely harbors a recombinant. According to Rubio et al. (2014), one of the main limitations of MAS is the genetic recombination between the marker and the gene.

To minimize errors in assisted selection resulting from recombination events that retain the marker but lose the gene, priority should be given to selecting individuals presenting all bands, preferably molecular markers flanking the gene. According to Mahé et al. (2008), markers Sat244 and BA-124-12K cosegregate $(0 \mathrm{cM})$ with the $\mathrm{S}_{\mathrm{H}} 3$ gene. The BA-48-21OR gene is located upstream of the $\mathrm{S}_{\mathrm{H}} 3$ gene at a distance of $0.6 \mathrm{cM}$; SP-M16- $\mathrm{S}_{\mathrm{H}} 3$ is located downstream at a distance of $1.8 \mathrm{cM}$. Thus, the presence of the four molecular markers was taken into account in the molecular analysis, identifying 127 genotypes (66.87\%) carrying the $\mathrm{S}_{\mathrm{H}} 3$ gene.
In addition to identifying the resistance gene, SPM16- $\mathrm{S}_{\mathrm{H}} 3$, Sat244, and BA-48-21OR also allowed the identification of homozygous and heterozygous individuals due to their codominant banding patterns. New recombinants were detected using this analysis. Considering the codominance pattern and recombination, four recombinants were observed for marker BA48-21OR, one recombinant for SP-M16- $\mathrm{S}_{\mathrm{H}} 3$, and one for Sat244.

The recombination observed for molecular markers M16- $\mathrm{S}_{\mathrm{H}} 3$ and BA-48-21OR can be justified by the distance between the molecular markers and the $\mathrm{S}_{\mathrm{H}} 3$ gene. According to Mahé et al. (2008), these markers flank the gene at a distance of 1.8 and $0.6 \mathrm{cM}$, respectively. Although these distances are small, recombination could have occurred between the marker and the gene. The closer a molecular marker is to the locus of interest, thereby reducing the possibility of recombination between them, the more effective is the MAS (Singh et al. 2001; Balachiranjeevi et al. 2015) and the use of molecular markers flanking a gene for resistance (Kelly et al. 2003; Kiguongo et al. 2014).

In the study carried out by Mahé et al. (2008), the Sat244 was found to be fully linked to the $\mathrm{S}_{\mathrm{H}} 3$ resistance gene, though a recombinant was identified in the present study. However, Mahé et al. (2008) estimated the distance between the molecular marker and the gene in a population different from that used in this study, with a smaller number of individuals, which may explain the results.

The choice of resistant and homozygous genotypes for a gene may lead to increased efficiency in gene introgression in breeding programs. Considering these two requirements, we were able to select and make 
available to breeders 11 coffee plants containing the $\mathrm{S}_{\mathrm{H}} 3$ gene in the homozygous condition. Such coffee plants may be recommended for use in breeding programs as parents for new crosses (backcrossing) with genetic materials of agronomic interest. Prakash et al. (2011) corroborate this result by demonstrating the importance of using molecular markers in assisted selection of resistant and homozygous coffee plants. In the present work, markers Sat244 and BA-124-12K-f, identified by Mahé et al. (2008), were analyzed in a population of Arabica cultivar S.795. Although this cultivar has been widely cultivated in India since 1947, over time, it has begun to show different levels of rust disease severity. This study was carried out to select genotypes with desired traits and homozygosity for the $\mathrm{S}_{\mathrm{H}} 3$ gene. Both molecular markers have proven to be quite reliable for confirming the presence of the $\mathrm{S}_{\mathrm{H}} 3$ gene, as well as the homozygous or heterozygous state (Prakash et al. 2011).

A spreadsheet containing other coffee plants with the gene in heterozygosity will also be made available. Considering that the resistance gene will segregate as heterozygous, these genotypes may be used and their progeny was evaluated with regard to coffee plants with other traits of economic interest.

Our results indicate that although the 160 coffee plants tested were introduced into Brazil as potential sources of resistance to rust and carrying the $\mathrm{S}_{\mathrm{H}} 3$ gene, 52 of them do not possess this gene because they did not present the appropriate marker, even in heterozygosity, when analyzed using the four molecular markers linked to the gene. However, when these coffee plants were inoculated with a mixture of pathogen races in Brazil, they were found to be resistant; thus, they may be carriers of genes other than $\mathrm{S}_{\mathrm{H}} 3$. Accordingly, these coffee plants were analyzed for another gene, $\mathrm{S}_{\mathrm{H}}$ ?, from other Coffea species, which is also effective in conferring resistance to rust.

Assisted selection for the $\mathrm{S}_{\mathrm{H}}$ ? gene of Híbrido de Timor conferring resistance to coffee rust

According to Diola et al. (2011), molecular markers CaRHvII 2 and CaRHvII 5 are located at a distance of 3.8 and $1.6 \mathrm{cM}$ upstream, respectively, of the $\mathrm{S}_{\mathrm{H}}$ ? gene, and CaRHvII 3 is at a distance of $0.9 \mathrm{cM}$ downstream of the $\mathrm{S}_{\mathrm{H}}$ ? gene. By analyzing these three molecular markers flanking the gene, a significant number (129) of genotypes that presented the markers linked to the resistance gene $\mathrm{S}_{\mathrm{H}}$ ? were found. This result was not expected because the 160 coffee plants of the study population are derived from a cross between Indian selections and $C$. arabica. Indian selections arose from the hybridization between $C$. arabica $\times C$. liberica, and this population does not show in its genealogy genetic material of the species C. canephora. $\mathrm{S}_{\mathrm{H}}$ ? was characterized by de Brito et al. (2010) in a Híbrido de Timor accession, and it has been suggested to be one of the genes previously identified in C. canephora. Therefore, this significant number of coffee plants suggests that the $\mathrm{S}_{\mathrm{H}}$ ? gene can also be found in materials derived from other coffee species.

Furthermore, it was found that 44 of the 129 genotypes identified as carrying the $\mathrm{S}_{\mathrm{H}}$ ? gene are among the 52 coffee plants that did not present the $\mathrm{S}_{\mathrm{H}} 3$ gene. Thus, this other gene may be responsible for the resistance observed in the field.

The three molecular markers validated for the $\mathrm{S}_{\mathrm{H}}$ ? gene showed a dominant nature. By analyzing recombination events, five recombinants were found for the CaRHvII 2, most likely because it is linked to the resistance gene at a distance of $3.8 \mathrm{cM}$ (Diola et al. 2011). Among the three molecular markers validated in this study, this was the greatest distance observed. Four recombinant coffee plants were found with CaRHvII 3 but only one with CaRHvII. According to Diola et al. (2011), these recombinants are located at 0.9 and $1.6 \mathrm{cM}$ from the gene, respectively. Therefore, our results are most likely due to differences in and to the sizes of the populations.

Seven promising coffee plants with two pyramided genes of resistance to rust were selected: UFV 311-48 $\left(\mathrm{F}_{2}\right)$, UFV 311-49 $\left(\mathrm{F}_{2}\right)$, UFV 311-56 $\left(\mathrm{F}_{2}\right)$, UFV 313-133 $\left(\mathrm{F}_{2}\right)$, UFV 334-65 $\left(\mathrm{F}_{2}\right)$, UFV 399-45 $\left(\mathrm{F}_{2}\right)$, and UFV 409-08 $\left(\mathrm{F}_{2}\right)$. These coffee plants carry the $\mathrm{S}_{\mathrm{H}} 3$ gene in homozygosity and the $\mathrm{S}_{\mathrm{H}}$ ? gene of Híbrido de Timor. Several other coffee plants carrying the $\mathrm{S}_{\mathrm{H}} 3$ gene in heterozygosity and the $\mathrm{S}_{\mathrm{H}}$ ? gene were also identified. The spreadsheet with these coffee plants and their respective genotypes will be made available to breeders.

In the case of coffee rust the causative agent of which presents high genetic variability and frequently overcomes resistance, it is important to establish a pyramid of genes for pathogen resistance to ensure durable resistance. According to Prakash et al. (2011), the action of accumulating genes into one genotype is difficult to achieve using traditional breeding methods. Thus, an efficient tool that can assist in this procedure is the use 
of molecular markers, which allow rapid and efficient inference of the presence of more than one resistance gene in a host genotype. Thus, when the objective is durable resistance by gene pyramiding, MAS provides several advantages to plant breeders (Melchinger 1990; Young 1999).

Assisted selection for the $C k-1$ gene conferring resistance to coffee berry disease

In Brazil, where the pathogen C. kahawae is absent, it is only possible to select materials resistant to CBD with molecular markers. Therefore, aiming at preventive breeding, we also evaluated the possibility of the studied population presenting the $C k-1$ gene, which confers resistance to this disease of great importance in coffee plants.

Three coffee plants carrying the $C k-1$ gene were identified by molecular analysis with the CBD-Sat235 molecular marker, and two coffee plants were identified using the CBD-Sat207. This result is because the CBDSat235 marker cosegregates with the $C k-1$ gene and CBD-Sat207 is located at an estimated distance of $17.2 \mathrm{cM}$ (Gichuru et al. 2008). Therefore, the recombination between CBD-Sat207 and the gene must have occurred. This fact demonstrates the importance of the availability of molecular markers close to the gene of interest and flanking the gene to decrease selection error (Kelly et al. 2003; Kiguongo et al. 2014; Rubio et al. 2014; Balachiranjeevi et al. 2015).

Because they present the resistance marker for both molecular markers for CBD, coffee plants UFV 317-12 $\left(F_{1}\right)$ and UFV 328-60 $\left(\mathrm{F}_{2}\right)$ are most suitable for coffee plant breeding programs aiming at resistance to coffee berry disease. When using more than one molecular marker, an increase in the efficiency and reliability of assisted selection is expected.

The UFV 328-60 $\left(\mathrm{F}_{2}\right)$ coffee can be recommended for use in plant breeding programs because it carries the $C k-1$ gene in homozygosity based on both validated molecular markers. However, this coffee did not present the $\mathrm{S}_{\mathrm{H}} 3$ and $\mathrm{S}_{\mathrm{H}}$ ? genes, which confer resistance to rust.

Coffee plant UFV 317-12 $\left(\mathrm{F}_{1}\right)$ presented the resistance marker for both molecular markers. However, it was found to be homozygous only for CBD-Sat207. In addition to carrying the $C k-1$ gene, this plant also carries the $\mathrm{S}_{\mathrm{H}}$ ? gene from Híbrido de Timor, which confers resistance to rust. Therefore, it already harbors a pyramid containing genes of resistance to rust as well as to CBD.

Utilizing the Sat235 marker to evaluate the occurrence of $C k-1$ in $C$. arabica cv. Ruiru 11 and their parental genotypes, Gichimu et al. (2014) also confirmed that this molecular marker is, in fact, linked to the studied gene, demonstrating its potential use in MAS aiming at resistance to $\mathrm{CBD}$, thus corroborating the results of this study.

\section{Conclusions}

Coffee plants carrying different genes of resistance to rust and CBD were identified in this study. Despite being derived from $C$. liberica, this germplasm carries the $\mathrm{S}_{\mathrm{H}} 3$ gene and the $\mathrm{S}_{\mathrm{H}}$ ? gene, which, to date, had only been identified in plants derived from C. canephora. The selected coffee plants are important sources for gene pyramiding in breeding programs aimed at multiple and durable resistance. Generations of selected individuals are being advanced, and the other agronomic traits are being evaluated in the field for the release of promising and resistant $C$. arabica varieties. The use of validated molecular markers linked to genes of resistance to rust and CBD is essential for monitoring different generations and crosses in breeding programs. This appears to be the first successful effort of achieving multiple host resistance to fungal diseases in arabica coffee by marker-assisted gene pyramiding.

Acknowledgements This work was financially supported by the Brazilian Coffee Research and Development Consortium (Consórcio Brasileiro de Pesquisa e Desenvolvimento do CaféCBP\&D/Café), by the Foundation for Research Support of the State of Minas Gerais (FAPEMIG), by the National Council of Scientific and Technological Development (CNPq), and by the National Institutes of Science and Technology of Coffee (INCT/Café).

\section{References}

Agwanda CO, Lashermes P, Trouslot P, Combes M, Charrier A (1997) Identification of RAPD markers for resistance to coffee berry disease, Colletotrichum kahawae, in arabica coffee. Euphytica 97:241-248. doi:10.1023/A:1003097913349

Balachiranjeevi C, Bhaskar NS, Abhilash V, Akanksha S, Viraktamath BC, Madhav MS, Hariprasad AS, Laha GS, Prasad MS, Balachandran SM, Neeraja CN, Satendra Kumar M, Senguttuvel P, Kemparaju KB, Bhadana VP, Ram T, Harika G, Mahadeva Swamy HK, Hajira SK, Yugander A (2015) 
Marker-assisted introgression of bacterial blight and blast resistance into DRR17B, an elite, fine-grain type maintainer line of rice. Mol Breed 35:151. doi:10.1007/s11032-015-0348-8

Bettencourt A, Rodrigues C (1988) Principles and practice of coffee breeding for resistance to rust and other diseases. In: Clarke R, Macrae R (eds) Coffee agronomy. Elsevier Applied Science, London, pp. 199-234

Cabral PGC, Zambolim EM, Zambolim L, Lelis TP, Capucho AS, Caixeta ET (2009) Identification of a new race of Hemileia vastatrix in Brazil. Australas Plant Dis Notes 4:129-130. doi:10.1071/DN09052

Cenci A, Combes M-C, Lashermes P (2012) Genome evolution in diploid and tetraploid Coffea species as revealed by comparative analysis of orthologous genome segments. Plant Mol Biol 78:135-145. doi:10.1007/s11103-011-9852-3

de Brito GG, Caixeta ET, Gallina AP, Zambolim EM, Zambolim L, Diola V, Loureiro ME (2010) Inheritance of coffee leaf rust resistance and identification of AFLP markers linked to the resistance gene. Euphytica 173: 255-264. doi:10.1007/s10681-010-0119-x

Diniz LEC, Sakiyama NS, Lashermes P, Caixeta ET, Oliveira AC, Zambolim EM, Loureiro ME, Pereira AA, Zambolim L (2005) Analysis of AFLP markers associated to the Mex-1 resistance locus in Icatu progenies. Crop Breed Appl Biotechnol 5:387-393. doi:10.12702/1984-7033.v05n04a03

Diola V, de Brito GG, Caixeta ET, Maciel-Zambolim E, Sakiyama NS, Loureiro ME (2011) High-density genetic mapping for coffee leaf rust resistance. Tree Genet Genomes 7:11991208. doi:10.1007/s11295-011-0406-2

Fernandez D, Tisserant E, Talhinhas P, Azinheira H, Vieira A, Petitot AS, Loureiro A, Poulain J, Da Silva C, Silva Mdo C, Duplessis S (2012) 454-pyrosequencing of Coffea arabica leaves infected by the rust fungus Hemileia vastatrix reveals in planta-expressed pathogen-secreted proteins and plant functions in a late compatible plant-rust interaction. Mol Plant Pathol 13: 17-37. doi:10.1111/j.1364-3703.2011.00723.x

Figueiredo A, Loureiro A, Batista D, Monteiro F, Várzea V, Pais MS, Gichuru EK, Silva MC (2013) Validation of reference genes for normalization of qPCR gene expression data from Coffea spp. hypocotyls inoculated with Colletotrichum kahawae. BMC Res Notes 6:388. doi:10.1186/1756-0500-6-388

Gartner GAL, McCouch SR, Moncada MDP (2013) A genetic map of an interspecific diploid pseudo testcross population of coffee. Euphytica 192:305-323. doi:10.1007/s10681-013-0926-y

Gichimu B, Gichuru E, Mamati G, Nyende A (2014) Occurrence of Ck-1 gene conferring resistance to coffee berry disease in Coffea arabica cv. Ruiru 11 and its parental genotypes. J Agric Crop Res 2:51-61

Gichuru EK, Agwanda CO, Combes MC, Mutitu EW, Ngugi ECK, Bertrand B, Lashermes P (2008) Identification of molecular markers linked to a gene conferring resistance to coffee berry disease (Colletotrichum kahawae) in Coffea arabica. Plant Pathol 57:1117-1124. doi:10.1111/j.1365-3059.2008.01846.x

Kelly JD, Gepts P, Miklas PN, Coyne DP (2003) Tagging and mapping of genes and QTL and molecular markerassisted selection for traits of economic importance in bean and cowpea. Field Crop Res 82:135-154. doi:10.1016/S0378-4290(03)00034-0

Kiguongo A, Omondi C, Gichuru E, Kasili R (2014) Analysis of simple sequence repeat markers linked to coffee berry disease resistance genes in a segregating population of arabica coffee (Coffea arabica L.). Int J Biotechnol Food Sci 2:156-166

Mahé L, Combes MC, Várzea VMP, Guilhaumon C, Lashermes P (2008) Development of sequence characterized DNA markers linked to leaf rust (Hemileia vastatrix) resistance in coffee (Coffea arabica L.). Mol Breed 21:105-113. doi:10.1007/s11032-007-9112-z

Maia TA, Maciel-Zambolim E, Caixeta ET, Mizubuti ESG, Zambolim L (2013) The population structure of Hemileia vastatrix in Brazil inferred from AFLP. Australas Plant Pathol 42:533-542. doi:10.1007/s13313-013-0213-3

Melchinger AE (1990) Use of molecular markers in breeding for oligogenic disease resistance. Plant Breed 104:1-19. doi:10.1111/j.1439-0523.1990.tb00396.x

Ortega F, Lopez-Vizcon C (2012) Application of molecular marker-assisted selection (MAS) for disease resistance in a practical potato breeding programme. Potato Res 55:1-13. doi:10.1007/s11540-011-9202-5

Prakash NS, Marques DV, Varzea VM, Silva MC, Combes MC, Lashermes P (2004) Introgression molecular analysis of a leaf rust resistance gene from Coffea liberica into C. Arabica L. Theor Appl Genet 109:1311-1317. doi:10.1007/s00122-004-1748-z

Prakash NS, Muniswamy B, Hanumantha BT, Sreenath HL, Sundaresha KD, Suresh N, Santhosh P, Soumya PR, Asha BM, Bhat SS (2011) Marker assisted selection and breeding for leaf rust resistance in coffee (Coffea arabica L.) - some recent leads. Indian J Genet Plant Breed 71:185-189

Ram AS (2006) Popular Indian coffee selections. Indian Coffee 70:12-18

Romero G, Vásquez LM, Lashermes P, Herrera JC (2014) Identification of a major QTL for adult plant resistance to coffee leaf rust (Hemileia vastatrix) in the natural Timor hybrid (Coffea arabica x C. canephora). Plant Breed 133: 121-129. doi:10.1111/pbr.12127

Rubio M, Ruiz D, Egea J, Martínez-Gómez P, Dicenta F (2014) Opportunities of marker-assisted selection for plum pox virus resistance in apricot breeding programs. Tree Genet Genomes 10:513-525. doi:10.1007/s11295-014-0700-x

Silva MC, Várzea V, Guerra-Guimarães L, Azinheira HG, Fernandez D, Petitot A, Bertrand B, Lashermes P, Nicole M (2006) Coffee resistance to the main diseases: leaf rust and coffee berry disease. Braz J Plant Physiol 18:119-147. doi:10.1590/S1677-04202006000100010

Singh S, Sidhu JS, Huang N, Vikal Y, Li Z, Brar DS, Dhaliwal HS, Khush GS (2001) Pyramiding three bacterial blight resistance genes (xa5, xa13 and Xa21) using marker-assisted selection into indica rice cultivar PR106. Theor Appl Genet 102:10111015. doi:10.1007/s001220000495

Van Der Vossen HAM, Walyaro DJ (1980) Breeding for resistance to coffee berry disease in Coffea arabica L. II. Inheritance of the resistance. Euphytica 29:777-791. doi:10.1007/BF00023225

Young N (1999) A cautiously optimistic vision for marker-assisted breeding. Mol Breed 5:505-510. doi:10.1023/A:1009684409326 